\title{
Meeting the Challenge of Transnational Crime
}

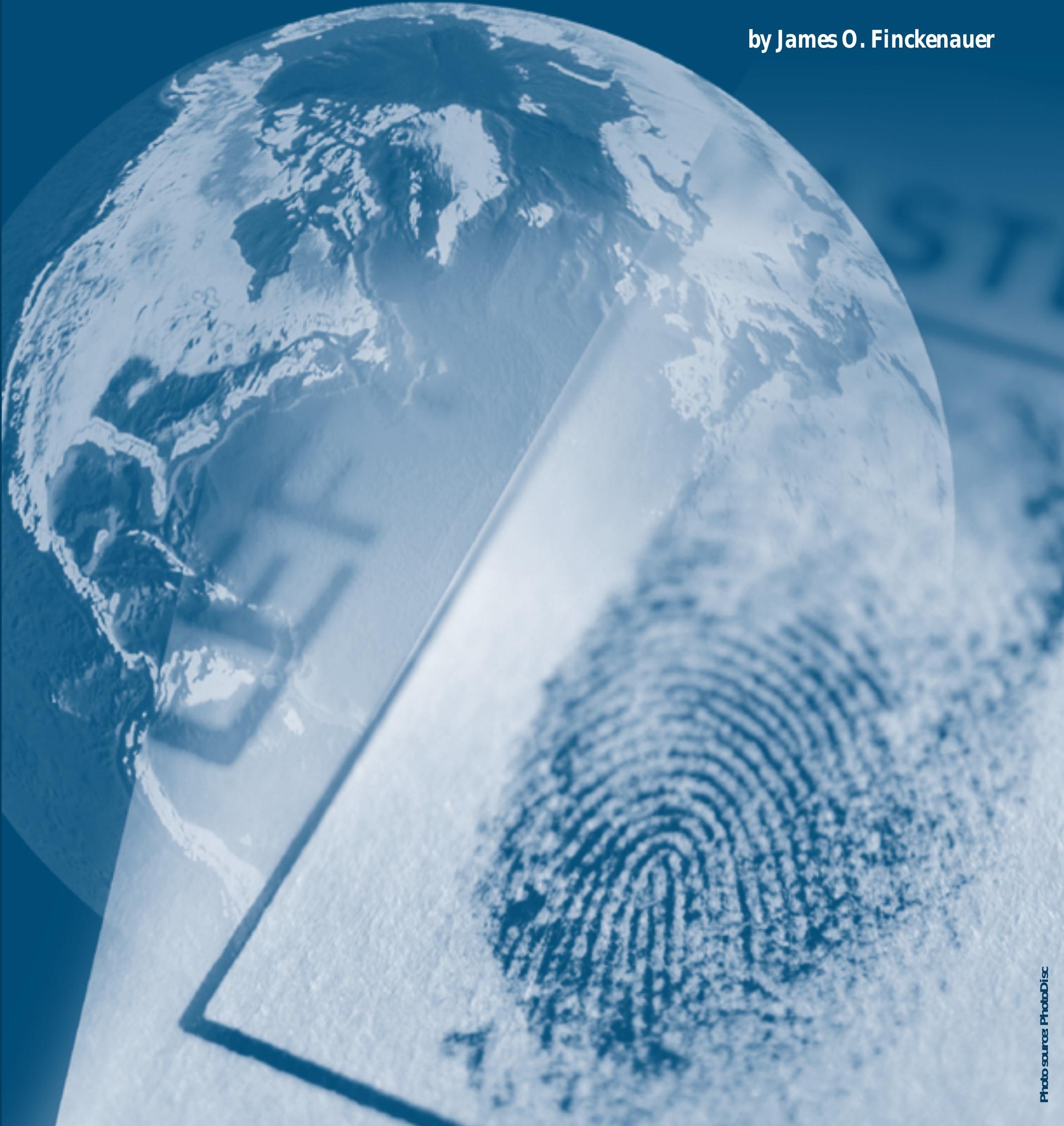


ust as many aspects of our lives have become part of a global village - transportation, communications, economic affairs- so, too, has crime taken on a global dimension. The same political and economic changes and technological advances that support easy international travel, communication, and business transactions also facilitate a criminal's ability to commit crimes that transcend borders. And because the United States is the world's richest country, it represents the most opportune target for transnational crime, which is defined by the United Nations as "offenses whose inception, prevention, and/or direct or indirect effects involve more than one country." ${ }^{1}$

For most of its history, NIJ could serve its primary constituentsState and local policymakers and practitioners- quite well by focusing on research and development within the borders of the United States. But criminal justice officials today are increasingly being asked to deal with offenses and offenders whose origins and connections lie outside the country. D rugs and drug offenders are the most obvious of these, but by no means the only

\section{about the author}

J ames $\mathrm{O}$. Finckenauer is the Director of $\mathrm{NIJ}$ 's International Center. His two most recent books are Scared Straight: The Panacea Phenomenon Revisited (1999) and Russian Mafia in America (1998). He is on leave from his position as Professor of Criminal J ustice at Rutgers, the State University of New J ersey.

ones. Transnational crimes include trafficked prostitutes from Southeast Asia or the former Soviet Union; migrant workers being exploited in sweatshops or farm fields; an array of credit card and banking frauds; automobiles stolen for shipment overseas; guns smuggled in an effort to evade regulation; and children trafficked through Canada and M exico for use by child pornography rings. And the list could go on.

The escalating threat associated with the new forms of crime was highlighted by a crime bill called the International Crime Control Act (ICCA) of 1998, which was introduced exactly 30 years after the Omnibus Crime Control and Safe Streets Act of 1968 created NIJ. This bill did not become law, but its goals are suggestive of problem areas needing attention on the international stage: denying safe haven to international fugitives, streamlining the investigation and prosecution of international crime ...immigration does not cause crime.

\section{The desire to immigrate, however,}

may cause people to violate immigration

\section{quotas and regulations and may lead to}

\author{
illegal immigration, which in turn is \\ exploited by criminals.
}

in U.S. courts, promoting global cooperation among law enforcement, and responding to emerging international crime problems.

\section{Factors That Make Transnational Crime Possible}

In a recent report of a workshop commissioned by NIJ, the National Research Council said that transnational crime was being affected by three related factors:

- Globalization of the economy.

- Increased numbers and heterogeneity of immigrants.

- Improved communications technology. ${ }^{2}$

These factors do not "cause" transnational crime. Rather, they facilitate crime, or in some cases, they are criminal opportunities in themselves. For example, immigration does not cause crime. The desire to immigrate, however, may cause people to violate immigration quotas and regulations and may lead to illegal immigration, which in turn is exploited by criminals.

Most of the causes of transnational crime are not new; they are, in fact, quite similar to factors that drive crime in general: disparate socioeconomic conditions, which stimulate migration and its antecedent trafficking in persons; the desire for illegal goods and services, which moves crime into the transnational real $m$ when the suppliers are in one country and the consumers are in another; and the universal greed for money and power. 
The Unique Challenges of Transnational Crime

The challenges in preventing and controlling transnational crime stem from several sources. For example, some crimes arise out of particular cultural or societal conditions and experiences that differ from one country to another. Behavior that is acceptable in one country may be illegal in another. Crimes that arise out of electronic communications, such as money laundering, are not bound by national borders. The whole panoply of so-called cybercrimes are almost by definition transnational crimes, since cyberspace is not constrained within these borders. The traditional desire to hide crime and elude law enforcement is met more fully by the increasing ease of global travel and communication.

The challenges in dealing with transnational crime arise from the national orientations of laws and law enforcement. Every country has its own laws and law enforcement system to deal with crime. But what about crime and criminals that cross national borders? Former Deputy Assistant Attorney General M ark M. Richard has noted that "the international community is not well positioned to respond to such issues [as foreign nationals committing a crime in the United States and escaping to their home country], [because] extradition and other procedures are archaic, based upon 19th century standards, and of limited use today." ${ }^{3}$

Ignoring the transnationalization of crime would be akin to adopting a "head in the sand" strategy. American police, prosecutors, judges, and corrections officials, as well as regulatory agencies- the customers for cutting edge research knowledge to help them understand

\title{
Ignoring the transnationalization of crime
}

\section{would be akin to adopting a "head in the sand"}

strategy. American police, prosecutors, judges, and corrections officials, as well as regulatory agencies- the customers for cutting edge research knowledge to help them understand and combat

\author{
crime- would be shortchanged by such \\ an outdated strategy.
}

and combat crime- would be shortchanged by such an outdated strategy. Both criminal justice practitioners and researchers would be forced to do their jobs with only partial and very limited information.

It was the recognition of this changing reality and of the ensuing need that led NIJ to create a new International Center in 1997.

\section{NIJ 's International Center's Challenge}

The International Center's mission is to stimulate and facilitate research and evaluation on transnational and comparative crime and justice issues and to disseminate the knowledge gained throughout the national and international criminal justice communities.

\section{Stimulate and Facilitate}

Research and Evaluation. To accomplish this aspect of its mission, the International Center motivates researchers (principally from the academic community, but not exclusively so) to study transnational crime and justice issues and to conduct comparative research (i.e, parallel studies conducted in more than one country about a topic that does not necessarily have transnational aspects). Comparative international research brings unique challenges (see "Challenges I nherent in Comparative International Research"), and the International Center has adopted an educational role in working with researchers whose approaches and methodologies may be foreign to each other.

In 1997, NIJ announced the International Challenge Grants to encourage American researchers to seek counterparts in other countries to conduct joint comparative studies. Of the first three projects funded under this program, two are transnational studies and one is comparative. The two transnational studies are examining human traf- 


\section{Challenges Inherent in Comparative International Research}

\author{
Grantees working on transnational \\ or comparative research issues \\ with international partners have \\ experienced a number of chal- \\ lenges common to this type \\ of research. Their experiences \\ indicate that all parties must \\ exercise creativity and willingness \\ to be innovative and open with one \\ another. The solution worked out \\ in one country may not work for \\ another research team in another \\ country - for example, what works \\ for an American-Ukrainian team \\ may not work for an American- \\ Chilean team.
}

Typical challenges include:

- Language barriers.

- Cultural differences. Issues about confidentiality and revealing the names of human subjects vary considerably from one country to another.

- Empirical standards. The rational-empirical standard in American social sciences often contrasts starkly with research approaches in other countries. For example, American researchers appreciate the value of the peer-review process, but this is not so everywhere.

- Methodological approaches. Comparative international researchers must develop an understanding of the various methodologies adopted by their counterparts and tolerate divergent methodologies. Parochialism and egocentrism will impair a project. ficking from China to the United States and trafficking of children through Canada and M exico to the United States. The comparative study is examining juvenile justice processing in Denver, Colorado, and Bremen, Germany. Both comparative and transnational studies can make unique contributions to our understanding of crime and justice issues, and study findings will have implications for criminal justice policy.

An example of how the International Center can stimulate evaluation comes from a request NIJ received from the U.S. Department of State. The United States funds several prison-based drug treatment programs in the Philippines and Thailand. Both countries are experimenting with therapeutic communities as their predominant drug treatment modality and as part of the U.S. drug demand reduction strategy. The State D epartment asked N IJ to visit the sites, assess the programs, and determine if their circumstances would permit a rigorous evaluation of the programs' effectiveness. After the International Center submitted its report, the State D epartment contacted American, Philippine, and Thai researchers who might conduct the evaluations.

The Center's International Visiting Fellowships are an example of how NIJ can facilitate research on transnational and comparative crime and justice issues. Three International Fellows have studied (1) transnational organized crime emanating from the former Soviet Union; (2) the organization of black markets, corruption, and crime in selected countries of the Newly Independent States (from Eastern Europe and the former USSR); and (3) restoration of civilian policing in countries that have undergone peacekeeping operations, such as Bosnia, Haiti, and Kosovo.

See "Special Initiatives," page 6, for activities that are making a significant contribution to our understanding of transnational crime.
Disseminate Knowledge. The International Center serves as an export-import bank of information through the exchange of ideas and knowledge among law enforcement agencies, academic institutions, and others in the criminal justice community, both here and abroad.

The means for this dissemination include reports, articles, books, and other materials in both paper and electronic formats.

Helping to link the International Center to the rest of the globe is the World Justice Information Network (WJIN) and the Internet Studio, operated by the Rule of Law Foundation under a cooperative agreement with $\mathrm{NIJ} .{ }^{4} \mathrm{WJIN}$ is an Internet-based community of some 6,000 criminal justice scholars and practitioners from more than 100 countries who share information through a global virtual library and an online forum.

Through links with WJIN and the National Criminal Justice Reference Service, the International Center 


\section{Special Initiatives}

Among the numerous initiatives that the International Center has undertaken during the past year are two that deserve special mention.

\section{Affiliation With the United Nations}

NIJ is a member of the UN Crime Prevention and Criminal J ustice Program Network, along with approximately a dozen regional and interregional institutes from around the world. The Center serves as $\mathrm{NIJ}$ 's principal liaison with these institutes and the UN Center for International Crime Prevention in Vienna, Austria.

Center staff have played a major role in assisting the UN as it mounts studies of transnational organized crime, corruption, and human trafficking. The Center is directly engaged in researching transnational organized crime groups operating in the United States as part of the UN's global study and has been assisting in the development of the UN Convention on Transnational Organized Crime.

The Center also organized a workshop on women as victims and survivors for the United Nations Congress held in Vienna, Austria, in April 2000. This workshop outlined a host of issues that need to be addressed by the global com- munity and presented examples of effective programs operating around the world.

\section{Partnership With Ukraine}

Perhaps the most challenging, but in many ways most exciting, activity during the past 2 years has been developing the United StatesUkraine Research Partnership, which operates within the framework of a joint United StatesUkraine commission called the Gore-Kuchma Binational Commission.

Funded with $\$ 1.1$ million from the State Department, this project supports American and Ukrainian researchers who are collaborating on joint studies of organized crime, drug trafficking, and human trafficking in Ukraine. The project is also assessing law enforcement training delivered to Ukrainians by Americans and is building Internet connectivity among American and Ukrainian researchers and practitioners. Results of the research partnership are expected toward the end of next year.

NIJ 's involvement in Ukrainian criminal justice issues illustrates a key raison d'etre for the International Center. Some might ask: Of what interest or value is Ukrainian criminal justice research to American criminal justice, and ultimately to American taxpayers? The answer is multifaceted.

First, Ukraine is the third largest recipient of U.S. foreign aid, it supports American interests in the former Soviet Union, and it is a repository of significant nuclear capability. Ukraine shares, with Colombia and Nigeria, the highest priority status of the State Department. The United States, thus, has an interest in helping Ukraine reduce crime and improve law enforcement as part of the effort to achieve political, economic, and social stability.

Second, the United States has invested heavily in law enforcement training in Ukraine. American policymakers and law enforcement participants need to know how effective the training has been.

Finally, and most practically, it is in America's best interests to assist Ukraine in solving its crime problems - whether they be in trafficking women, children, drugs, arms, or nuclear materials, or in some type of organized crimebefore they spill over the borders into Europe and the United States. By doing so, NIJ helps to achieve the crime control and safe streets goals set for it 30 years ago. provides a portal to the world's largest database of criminal justice literature for both a domestic and an international audience.

Dissemination also takes place through conferences, meetings, and workshops of various kinds. For example, in 1998 the International Center coordinated or participated in nearly 40 meetings for international visitors to the Office of Justice Programs and NIJ.
These meetings involved 117 visitors from 34 countries who learned about research being conducted in the United States and about how to initiate and maintain an exchange of information with NIJ. In cooper- 


\section{Crimes that originate in one country}

\section{and occur in another and criminals}

who migrate across national borders have

become almost commonplace. As this

phenomenon changes the face of

American crime, NIJ 's International Center

will continue to advance awareness of

these types of crime and knowledge of how

to respond to them. ation with Howard University's

South Africa studies program, the

Center cohosted a workshop on

treatment, training, and health care

in South African prisons and jails

for South Africa's M inister of

Correctional Services.

In the years leading up to the creation of NIJ over 30 years ago, crime in America was very much a domestic issue fueled by crime in the streets, urban riots, disregard for law and order, and poor policecommunity relations. Concerns about international crime were virtually non-existent. With the exception of a few issues, such as drug smuggling, transnational crime was not considered a major problem at that time.
Today, more than three decades later, the crime situation in the United States is vastly different. Crimes that originate in one country and occur in another and criminals who migrate across national borders have become almost commonplace. As this phenomenon changes the face of American crime, $\mathrm{NIJ}$ 's International Center will con- tinue to advance awareness of these types of crime and knowledge of how to respond to them.

NCJ 183454

\section{Notes}

1. "Results of the supplement to the Fourth United Nations Survey of Crime Trends and O perations of Criminal Justice Systems, on Transnational Crime (Interim report by the Secretariat)," United Nations, April 4, 1995.

2. Peter Reuter and Carol Petrie, eds., Commission on Behavioral and Social Sciences and Education, Transnational Organized Crime: Summary of a Workshop, Washington, D.C.: National Academy Press, 1999.

3. Statement from a focus group conducted by NIJ's International Center, M arch 19, 1999.

4. The Rule of Law Foundation, a nonprofit organization based in ful history of implementing international projects related to the design and development of Internet-based information systems for criminal justice. Washington, D.C., has a success-

\section{For More Information}

- Visit NIJ 's International Center at http://www.ojp.usdoj.gov/nij/international.

- Visit the World J ustice Information Network, a part of NIJ 's effort to create links around the globe, at http://www.justinfo.net.

- Contact the International Center at 810 Seventh Street NW., Washington, DC 20531, e-mail: intlcntr@ ojp.usdoj.gov. 